НАУКОВИЙ ВІСНИК

scientific messenger of Lvir National University of

7

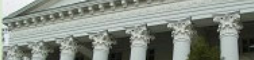

(1)

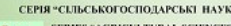

Науковий вісник Дьвівського національного університету ветеринарної медицини та біотехнологій імені С.3. Гжицького. Серія: Сільськогосподарські науки

Scientific Messenger of Lviv National University of Veterinary Medicine and Biotechnologies. Series: Agricultural sciences

UDC 574:379.8:338.48

\title{
Analysis of the state of recreational and tourist activity in Yavoriv National Nature Park
}

T. B. Nahirniak

Stepan Gzhytskyi National University of Veterinary Medicine and Biotechnologies Lviv, Ukraine

Article info

Received 18.02.2020

Received in revised form 19.03.2020

Accepted 20.03.2020

Stepan Gzhytskyi National University of Veterinary Medicine and Biotechnologies Lviv, Pekarska Str., 50, Lviv.

79010, Ukraine.

$\mathrm{Tel} \cdot+38-063-387-66-95$

E-mail:ntb08@ukr.net
Nahirniak, T. B. (2020). Research of the natural resource and recreational potential of the Rohatyn district of Ivano-Frankivsk region. Scientific Messenger of Lviv National University of Veterinary Medicine and Biotechnologies. Series: Agricultural sciences, 22(92), 108-112. doi: $10.32718 /$ nvlvet-a9218

The article analyzes the sites of Yavoriv National Nature Park, which are of great recreational and tourist importance. The features of the development of ecological tourism in Yavoriv National Nature Park are highlighted, the tourism and resource potential of the park is estimated. The problems and prospects of using the region's recreational and tourism resources were noted. The reasons for hindering the further development of the tourist and recreational industry in the park are indicated. National nature parks create a unique opportunity to coordinate the tasks of nature conservation with the needs of balanced use of natural resources and rest of the population. Yavoriv National Nature Park is a catalyst for the sustainable development of the region and a base for the development of recreational, tourist, environmental, environmental, scientific, as well as an incentive for the development of related types of entrepreneurial activity in the area. Information on the species diversity of the park makes it possible to develop and implement measures aimed at preserving biotic, ecosystem, landscape diversity, sustainable nature and improving the socio-economic standard of living of the local population. Yavoriv National Nature Park has significant natural, historical and cultural resources. There are many attractive places for the development of cognitive tourism: numerous picturesque hills-remains with rocky outcrops of massive limestones and calcareous sandstones, caves, boulders of Scandinavian origin; favorable conditions have also arisen for the development of various types of tourism: local cognitive, sacral, sports (hiking, horseback, cycling), skilled tourism (fishing). Recreational activities on the territory of the park are a direct investment in the economic development of the region, it is carried out by creating favorable conditions for visitors' recreation and covers: arrangement of ecological and tourist routes and recreation areas; organization of ecological camps for schoolchildren and youth; involvement of the local population in recreational activities (provision of paid services for visitors in accommodation, meals and support); providing information services through print, photo and video production, production of information stands; Attraction and cooperation with the recreational institutions of the region to visit the park territory.

Key words: Yavoriv National Nature Park, natural resources, recreation, tourism, ways of improving activities.

\section{Аналіз стану рекреаційно-туристичної діяльності в Яворівському національному природному парку}

\author{
Т. Б. Нагірняк
}

Львівський національний університет ветеринарної медицини та біотехнологій імені С. 3. Гжицького, м. Львів, Україна

У статті проаналізовано об'єкти Яворівського національного природного парку, які мають важливе рекреаційно-туристичне значення. Висвітлені особливості розвитку екологічного туризму в Яворівському начіональному природному парку, оцінено туристично-ресурсний потенціал парку. Відзначено проблеми та перспективи використання рекреаційно-туристичних ресурсів регіону. 
Вказано на причини, які гальмують подальший розвиток туристично-рекреаційної галузі в парку. Національні природні парки створюють унікальну можливість узгодження завдань охорони природи з потребами збалансованого використання природних ресурсів і відпочинком населення. Яворівський національний природний парк є каталізатором сталого розвитку регіону та базою для розвитку рекреаційної, туристичної, еколого-освітньої, природоохоронної, наукової діяльності, а також стимулом для розвитку супутніх видів підприємницької діяльності в районі. Інформація про видове різноманіття парку дає змогу розробляти і впроваджувати заходи, спрямовані на збереження біотичного, екосистемного, ландшафтного різноманіття, невиснажливого природокористування та поліпшення сочіально-економічного рівня життя місиевого населення. Яворівський національний природний парк володіє значними природними та історико-культурними ресурсами. Тут чимало привабливих місиь для розвитку пізнавального туризму: численні мальовничі горби-останці зі скельними виходами масивних вапняків і вапнистих пісковиків, печери, валуни скандинавського походження; склалися сприятливі умови і для розвитку різних видів туризму: краєзнавчо-пізнавального, сакрального, спортивного (пішого, кінного, велосипедного), кваліфікованого туризму (рибальство). Рекреаційна діяльність на території парку є прямою інвестицією в економічний розвиток регіону, вона здійснюється шляхом створення сприятливих умов для відпочинку відвідувачів і охоплює: облаштування екологічних та туристичних маршрутів $і$ зон відпочинку; організацію екологічних таборів для школярів та молоді; залучення місцевого населення до рекреаційної діяльності (надання платних послуг відвідувачам щчодо розміщення, харчування та супроводу); надання інформаційних послуг через випуск друкованої, фото- та відеопродукції, виготовлення інформаційних стендів; залучення та співпрачя з рекреаційними закладами регіону щцодо відвідування території парку.

Ключові слова: Яворівський начіональний природний парк, природні ресурси, рекреація, туризм, шляхи удосконалення діяльноcmi.

\section{Вступ}

На даний час в рамках еколого-організаційної структури, що сформована в Україні, важливою є роль природоохоронних територій, які мають формувати окремі елементи та цілі вузли національної екологічної мережі. Національні природні парки $є$ місцем, де розробляються підходи та впроваджуються методики раціональної взаємодії людини та природи, знаходять практичне втілення принципи сталого природокористування та господарювання, формуються механізми управління природоохоронними заходами та формуються елементи екологічної свідомості населення.

На сучасному етапі туризм набуває не просто масового характеру, а стає однією з провідних, високоприбуткових та найдинамічніших галузей світового господарства. Специфічною рисою туристичнорекреаційної сфери є те, що вона поєднує в собі понад 50 суміжних галузей: культуру, мистецтво, науку, освіту, спорт, готельне господарство, медицину, торгівлю, харчування, транспорт, зв'язок, фінанси, побут, народні промисли, розваги, будівництво та ін. Тому кожна країна, регіон, місто намагаються пропагувати та популяризувати свою туристичну привабливість.

Територія Яворівського району з його унікальними історико-культурною спадщиною, мистецтвом, лікувально-оздоровчими, водними і ландшафтними ресурсами, самобутніми традиціями та звичаями в поєднанні 3 вигідним географічним положенням $є$ чудовою базою для розвитку найрізноманітніших видів і форм туризму та відпочинку. Об'єктивно оцінюючи туристично-рекреаційні можливості Яворівщини, можна стверджувати, що регіон має передумови для перспективного розвитку культурнопізнавального, лікувально-оздоровчого, природничопізнавального, науково-освітнього, релігійного, мисливського, екологічного, водного, етнічного, спортивно-оздоровчого, ділового, відпочинковорозважального, активного, екскурсійного туризму.

У статті ставимо за мету розкрити сучасний стан та перспективи розвитку рекреації та туризму в межах території Яворівського національного природного парку.

\section{Результати та їх обговорення}

Яворівський національний природний парк (НПП) розташований на території Українського Розточчя одного з найцікавіших фізико-географічних районів Західної України. За фізико-географічним районуванням - це Розтоцький район Розтоцько-Опільської геоботанічної області Західноукраїнської провінції лісостепової зони.

Українське Розточчя являє собою вузьке (в середньому 25 км) горбогірне пасмо довжиною 75 км, яке на півночі різко підіймається над Малим Поліссям. У південно-східній частині його проходить Головний Європейський вододіл, на схилах якого беруть початок річки, що належать до басейнів двох морів - Чорного і Балтійського (Stratehiya rozvytku Yavorivs'koho rayonu..., 2016).

Парк засновано 4 липня 1998 року на площі 7108 га, у тому числі 2915 га надані в постійне користування. До його складу входять території користувачів без вилучення у них земель, а саме: Магерівське лісництво Магерівського військового лісгоспу площею 917 га i Майданське лісництво Старицького військового лісгоспу площею 3276 га. Територія парку простягається своєрідним півмісяцем від с. Верещиця Яворівського району до с. Крехів Жовківського району, його довжина зі заходу на схід - 12-13 км, а 3 півночі на південь - від 2,5 до 12 км. На півдні парк межує 3 природним заповідником "Розточчя", а на півночі - 3 навчальним полем Яворівського учбового центру ЗОК МО України, відомим як Яворівський полігон. У західній частині парку протікає річка Верещиця, яка впадає у Дністер. У межах парку беруть свій початок ліві притоки Верещиці - річки Ставчанка і Стара Ріка. На півночі -витоки річок Дерев'янки і Свині (басейн річки Західного Бугу).

На території парку зареєстровано 9 видів тварин, занесених до Європейського червоного списку, 34 види, що занесені до Червоної книги України та 146 видів тварин, які підлягають особливій охороні згідно з Бернською конвенцією.

У парку встановлено диференційний режим охорони згідно з функціональним зонуванням. Тут $є$ умови для розвитку еколого-пізнавального, культурологі- 
чного, спортивного (кінного, велосипедного) туризму. Біля адміністративного корпусу закладено дендропарк, у приміщенні обладнаний екологопросвітницький центр, виставки.

Яворівський НПП володіє також історикокультурними ресурсами - унікальними історикокультурними об'єктами, які розташовані в межах парку та поблизу його території. Тут відкрито низку унікальних археологічних об'єктів, 3 яких найбільш відоме княже городище Щекотин, що поблизу сучасного с. Глинське. Також поблизу Яворівського НПП є низка споруд української сакральної архітектури.

Усі ці ресурси співробітники парку активно залучають для розвитку рекреаційно-туристичної діяльності. У парку створений відділ рекреації та екологічної освіти, працівники якого, зокрема, створюють умови для повноцінного відпочинку людей в місцях стаціонарної рекреації, а також проводять екскурсійну та екоосвітню діяльність, постійно підтримують зв'язок з громадськістю та освітніми закладами різних рівнів (Kadnichans'ka, 2013).

Отож, рекреаційно-туристична діяльність парку має такі основні напрями: відпочинок (загальнооздоровчий, культурно-пізнавальний, короткостроковий від 5-10 годин до 1-2 днів 3 розкладанням наметів і вогнищ у спеціально обладнаних та відведених для цього місцях); екскурсійна діяльність (екскурсії маркованими екологічними стежками та маршрутами до визначних культових споруд і пам'ятних місць регіону, на виставки, в музеї); туристична діяльність (науково-пізнавальний пішохідний, орнітологічний, етнографічний, велосипедний, кінний, водний, а також утилітарний туризм - збирання грибів, ягід; любительське і спортивне рибальство.

Зважаючи на сприятливі природні умови, національний парк має також великий рекреаційний потенціал і є цікавим об'єктом екотуризму. 3 цією метою 35 \% території парку відведено для зони регульованої рекреації.

В цілях рекреаційного використання створені водойми загальною площею 9,0 га. Щорічно місця масового відпочинку відвідує близько 9 тис. відпочиваючих, а екскурсійними шляхами Яворівського НПП проходить понад 3 тис. туристів (Plan adaptatsiyi..., 2016).

У парку є чотири зони стаціонарної рекреації: “Верещиця", “Козулька", “Лелехівка", “Середній Горб”, а також рекреаційно-атракційний об’єкт “Оселя Розточчя”, екологічні стежки, туристичні маршрути, п'ять рекреаційних водойм (Kadnichans'ka, 2013).

Зона стаціонарної рекреації "Верещиця” розташована поблизу села Верещиця Яворівського району Львівської області, іiї площа становить 17,6 га, територія облаштована та пристосована для довготривалого відпочинку. Тут побудовано дві рекреаційні водойми, зону стаціонарної рекреації підключено до системи енергозабезпечення, сформована мережа водозабезпечення та водовідведення, встановлено очисні споруди, облаштовано зону відпочинковими навісами (16 шт.), лісовими меблями, збудовано чотири літніх відпочинкових будиночки, функціонують пляж, рятувальний пост, збудовано огорожу, побудо- вано причали та містки для спортивної риболовлі, проведено зариблення, наявні плавзасоби - 3 човни та 2 водні велосипеди.

Зона стаціонарної рекреації “Лелехівка" поблизу с. Лелехівка Яворівського району Львівської області (площа - 2,5 га) облаштована літніми навісами (15 шт.), мангалами, малими архітектурним формами, лісовими меблями, контейнерами для сміття.

Зона стаціонарної рекреації "Козулька" поблизу с. Козулька Жовківського району Львівської області (площа - 6,6 га) розташована в північній частині парку, поблизу Крехівського монастиря й облаштована відпочинковими навісами (10 шт.), мангалами, малими архітектурним формами, лісовими меблями, контейнерами для сміття. Підготовлені водойми для купання та спортивно-любительської риболовлі, проведено зариблення.

Зона стаціонарної рекреації "Середній Горб” розташована поблизу с. Середній Горб Яворівського району Львівської області (площа - 3,5 га), облаштована літніми навісами (3 шт.), мангалами, контейнерами для сміття.

Рекреаційно-атракційний об'єкт “Оселя Розточчя” розташований поблизу с. Дубровиця Яворівського району Львівської області (площа становить 2,4 га). Тут в загінному утриманні перебувають нащадки дикого тарпана - польські коники (6 особин), на території є: оселя, що раніше слугувала господою для лісника (3 ліжкомісця); кімната старожитностей українського села; пасіка; господарський двір (вівці, свині, кролі, качки, гуси); криниця глибиною 38 м; три відпочинкові навіси. Зроблено перші кроки для розвитку кінного туризму.

Через територію парку прокладено екологопізнавальні стежки "Стежка Івана Франка" та "Крехівські святині”. Еколого-літературна “Стежка Івана Франка" довжиною 1,1 км проходить через лісовий масив поблизу с. Лелехівка. Час проходження маршруту разом із зупинками по 15 хв на оглядових точках - близько 1,5 год. Стежка облаштована малими архітектурними формами, лісовими меблями, парковими скульптурами та композиціями героїв творчості Івана Франка. Важливим оглядовим об'єктом є Біла скеля степова гостя Розточчя. Завершується стежина каскадом Чорних озер.

Природничо-релігійна стежка "Крехівські святині" довжиною 2,5 км проходить через лісовий масив поблизу Крехівського монастиря (село Крехів Жовківського району Львівської області). Час проходження стежки 1,5 год. Стежка пролягає через мальовниче урочище Рубаня у районі гори Побійної, поблизу Крехівського монастиря. Стежка облаштована аншлагами, вказівниками та інформаційною атрибутикою. Тут у великому камені Тимоша монахи започаткували монастир (кінець XVI ст.), також важливе історикосакральне значення має Святе джерело Пресвятої Богородиці.

Через територію парку прокладено чотири еколого-пізнавальних маршрути: “Верещиця", “Лелехівка”, “Голуби”, "Головним європейським вододілом". Серед інших атракційних об’єктів - гора Прислін (місце ранньосередньовічного городища), скельні виходи 
ратинських вапняків, давня сільська криниця "Вовча яма”, поховання німецьких військовополонених часів Другої світової війни. Рано навесні у парку вражає розмаїття ефемероїдів, що вкривають все довкола.

Еколого-пізнавальний маршрут "Головним європейським вододілом" довжиною 4 км проходить в районі с. Млинки Яворівського району Львівської області. Час проходження маршруту разом зі зупинками по 15 хв на оглядових точках - біля 3 год. Маршрут має інформаційне забезпечення (карта-схема маршруту, аншлаги, вказівники, лісові меблі). Проходить стежка хребтом Головного європейського вододілу, де беруть свій початок численні річки Розточчя (Фійна, Кислянка, Верещиця, Ставчанка та ін.), що несуть свої води в басейн Чорного і Балтійського морів. Маршрут відкриває чудові краєвиди Розточчя. Завершальним оглядовим об'єктом стежки є рекреаційно-атракційний осередок “Оселя Розточчя”.

Також працівниками парку розроблено туристичні маршрути: три піших (“На гору Березняки”, “На гору Булава", “На гору Кубин”) та п’ять автобусно-піших (“Страдч-Чорні озера”, “Шляхами Розточчя від Янова до Крехова”, “Яворівський військовий полігон: минуле та сучасність”, “Яворівські околиці”, “Вікова історія Янова”), які залучають ресурси околиць парку.

3 метою організації рекреаційно-туристичної та екоосвітньої діяльності відділ рекреації та екологічної освіти співпрацює з туристичними структурами Львова, низкою навчальних закладів, Державним природознавчим музеєм НАН України. Співпраця передбачає наукові дослідження на території парку, організацію практик студентів, написання на базі парку курсових і дипломних робіт, організацію екскурсійної діяльності. Також проводяться семінари старшокласників, лекції на природоохоронну тематику, екологічні уроки (Ofitsiynyy sayt Yavorivs'koho NPP).

На території Яворівського НПП останнім часом набув популярності подієвий туризм. Працівники відділу рекреації та екологічної освіти організовують різні святкування та акції із залученням великої кількості відвідувачів.

Водночас подальший розвиток туристичнорекреаційної галузі гальмується в парку через: низький рівень розвитку туристично-рекреаційної інфраструктури; невідповідність закладів розміщення світовим стандартам; незадовільний стан доріг; відсутність під'їздів до багатьох туристичних об'єктів; недостатню кількість дорожніх вказівників і туристично-інформаційних знаків, місць короткочасного відпочинку вздовж доріг; незадовільний стан пам'яток історико-архітектурної спадщини, що не підлягають використанню для туристичних потреб; слабку взаємодію місцевих органів виконавчої влади та органів місцевого самоврядування щодо забезпечення розвитку туризму і рекреації в регіоні; недостатність методичної, організаційної, інформаційної та матеріальної підтримки з боку держави суб'єктів туристичної діяльності, які здійснюють організацію прийому туристів в області; недостатній асортимент туристичних послуг; неналежний стан туристичних маршрутів (брак обладнаних місць короткочасного відпочинку); недостатність туристичної інформації як для туристів, так і для підприємств, що надають послуги у сфері туризму (карт, рекламної продукції, інформації про район, недосконалість бази даних щодо туристичнорекреаційних об'єктів); неефективне використання туристично-рекреаційного потенціалу в сільській місцевості як одного з чинників зменшення безробіття.

Усі ці проблеми зумовлюють необхідність створення повноцінної регіональної політики щодо розвитку туризму та рекреації.

Важливим завданням національних природних парків України, серед них і НПП “Яворівського”, є уПравління (планування, організація, координація, контроль) рекреаційною (туристичною) діяльністю, зокрема відвідуванням території. Здійснення такої екотуристичної діяльності (організація збуту туристських послуг, турів) на природно-заповідних територіях покладається на спеціалізовані державні та комерційні (а також спільні акціонерні) структури - туристичні фірми.

Вважаємо, що для розвитку екологічного туризму потрібно керуватися такими засадами: наближеність до природи i використання переважно природних ресурсів; збереження первозданності навколишнього середовища; пріоритетність екологічного утворення, формування відносин рівноправного партнерства 3 природою; збереженість місцевого соціокультурного середовища; економічна ефективність і стійкий розвиток тих районів, де проходять тури.

Основними проблемами, які треба вирішити для розвитку екологічного туризму в парку, є: вдосконалення економічного механізму надання платних туристичних послуг, створення на засадах самозабезпечення, самофінансування та самоокупності госпрозрахункових рекреаційних структурних підрозділів парку; забезпечення парку рекреаційно-туристичною інфраструктурою відповідно до міжнародних стандартів (умови проживання і харчування туристів, транспортні засоби, спостережні вежі); інвентаризація та кількісно-якісна оцінка наявних на природнозаповідних територіях рекреаційних природних (бальнеологічних, кліматичних, лісових, пейзажних) та історико-культурних ресурсів (Pan'kiv, 2019); формування у туристів, відпочивальників інтелектуальногуманістичного світобачення та патріотичного ставлення до природної і культурної спадщини.

Проте загалом Яворівський національний природний парк $є$ флагманом з розвитку екологічно спрямованих видів туристично-рекреаційної діяльності в Українському Розточчі, а також одним із найактивніших популяризаторів збереження та раціонального використання природної й історико-культурної спадщини цього унікального регіону з високою заповідністю та давніми традиціями господарського освоєння.

\section{Висновки}

Встановлено, що завдяки сприятливим природним умовам Яворівський національний природний парк має значний рекреаційний потенціал i $\epsilon$ цікавим об'єктом туризму. Так, парк сприяє екологізації різних напрямків господарської діяльності, що здійсню- 
ються на його території (лісове, водне і мисливське господарство).

Регіон, в якому розташований Яворівський національний природний парк, надзвичайно багатий на археологічні та історико-культурні пам'ятки. Тут відкрито низку стоянок давньої людини та городища княжої доби. Серед лісових масивів часто трапляються мальовничі галявини та залишки фруктових садів пам'ять про колишні села і хутори, звідки виселили людей під час створення полігону.

Розвиток екологічного туризму в регіоні сприятиме: вирішенню соціально-економічних проблем населення; зменшенню рівня безробіття у сільській місцевості та розширенню кола зайнятості сільського населення, особливо молоді; розширенню можливостей реалізації продукції особистого підсобного господарства; покращенню благоустрою сільських садиб, вулиць, загалом сіл; розвитку соціальної інфраструктури; відродженню, збереженню і розвитку місцевих народних промислів, пам'яток історико-культурної спадщини; підвищенню культурно-освітнього рівня сільського населення.

Раціональне освоєння потенціалу національного природного парку забезпечить не тільки збільшення надходження фінансових ресурсів, зайнятість працівників у рекреаційній сфері, а й розширення сфери оздоровлення.

Перспективи подальших досліджень. Нині є тенденції щодо створення природоохоронних територій та установ нового типу, зокрема міжнародних біосферних резерватів, які зазвичай потребують принципово нових підходів і методів збереження їхнього фіторізноманіття. Тому в майбутньому саме вони потребуватимуть грунтовного аналізу сучасної видової й синтаксономічної різноманітності рослинного покриву, узагальнення наявних даних про флору й рослинність території, іiі динаміку, а також змін у формах рекреаційно-туристичної діяльності.

\section{References}

Kadnichans'ka, M. (2013). Aspekty rekreatsiynoturystychnoyi diyal'nosti v Yavorivs'komu natsional'nomu pryrodnomu parku. Visnyk L'vivs'koho universytetu. Seriya heohrafichna, 43(1), 38-44. doi: 10.30970/vgg.2013.43.1538 (in Ukrainian).

Ofitsiynyy sayt Yavorivs'koho NPP [Elektronnyy resurs]. Rezhym dostupu: http://yavorpark.in.ua (in Ukrainian).

Pan'kiv, N. Y. (2019). Pryrodookhoronni terytoriyi yak baza rozvytku ekolohichnoho turyzmu u L'vivs'kiy oblasti na prykladi natsional'noho pryrodnoho parku "Skolivs'ki beskydy". Naukovyy visnyk NLTU Ukrayiny, 29(5), 88-92. doi: 10.15421/40290517 (in Ukrainian).

Plan adaptatsiyi mistsevykh hromad Yavorivshchyny (Roztochchya, L'vivs'ka obl.) do naslidkiv zminy klimatu $\mathrm{V}$ umovakh terytoriyi $\mathrm{z}$ vysokym pryrodookhoronnym statusom (2016). Ivano-Frankove, L'viv (in Ukrainian).

Stratehiya rozvytku Yavorivs'koho rayonu do 2020 roku (2016). Yavoriv (in Ukrainian). 